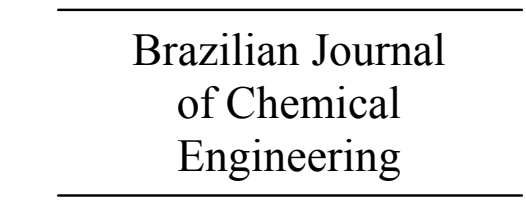

ISSN 0104-6632

Printed in Brazil

www.abeq.org.br/bjche

Vol. 30, No. 01, pp. 63 - 73, January - March, 2013

\title{
MODELING VAPOR LIQUID EQUILIBRIUM OF IONIC LIQUIDS + GAS BINARY SYSTEMS AT HIGH PRESSURE WITH CUBIC EQUATIONS OF STATE
}

\author{
A. C. D. Freitas, L. P. Cunico, M. Aznar and R. Guirardello* \\ School of Chemical Engineering, State University of Campinas, (UNICAMP), \\ Phone: + (55) (19) 3521 3955, Fax: + (55) (19) 35213910 , \\ Av. Albert Einstein 500, 13083-852, Campinas - SP, Brazil. \\ E-mail: acdfreitas@feq.unicamp.br; laracunico@gmail.com; \\ maznar@feq.unicamp.br; "guira@feq.unicamp.br
}

(Submitted: February 1, 2012 ; Revised: July 7, 2012 ; Accepted: July 11, 2012)

\begin{abstract}
Ionic liquids (IL) have been described as novel environmentally benign solvents because of their remarkable characteristics. Numerous applications of these solvents continue to grow at an exponential rate. In this work, high pressure vapor liquid equilibria for 17 different IL + gas binary systems were modeled at different temperatures with Peng-Robinson (PR) and Soave-Redlich-Kwong (SRK) equations of state, combined with the van der Waals mixing rule with two binary interaction parameters (vdW-2). The experimental data were taken from the literature. The optimum binary interaction parameters were estimated by minimization of an objective function based on the average absolute relative deviation of liquid and vapor phases, using the modified Simplex algorithm. The solubilities of all gases studied in this work decrease as the temperature increases and increase with increasing pressure. The correlated results were highly satisfactory, with average absolute relative deviations of $2.10 \%$ and $2.25 \%$ for PR-vdW-2 and SRK-vdW-2, respectively.

Keywords: Ionic liquids; Vapor-liquid equilibria; PR and SRK Eos.
\end{abstract}

\section{INTRODUCTION}

Ionic liquids are organic salts that are liquid at room temperature and consist of a small organic or inorganic anion and a large asymmetric organic cation. Ionic liquids have negligible vapor pressure and a stable and wide liquid range of over $300 \mathrm{~K}$. These fluids have been proposed as attractive alternatives to volatile organic compounds for green processes (Blanchard and Brennecke, 2001).

Ionic liquids have been described as novel environmentally benign solvents because of their remarkable characteristics, such as non-volatility, high thermal stability, non-flammability and high polarity (Anthony et al., 2001; Fadeev et al., 2001). Numerous applications of these solvents continue to grow at an exponential rate; the most common applications found in the literature are in gas and liquid separation processes (Blanchard and Brennecke, 2001; Anthony et al., 2001; Fadeev et al., 2001;Visser et al., 2000); as solvents in various reactions systems, such as hydrogenation, hydroformylations, isomerizations, dimerizations, alkylations, among others (Welton, 1999; Hermann et al., 1999; Seddon, 1995; Blanchard et al., 2001); in electrolytes/fuel cells (Souza et al., 2003); as $\mathrm{CO}_{2}$ selective separation media (Anthony et al., 2002; Zhang et al., 2006); in the capture or sequestration of

*To whom correspondence should be addressed

This article is an extended version of a work presented at CBTermo-2011 - VI

Brazilian Congress of Applied Thermodynamics 2011, Salvador, Bahia, Brasil. 
various gases such as $\mathrm{CO}_{2}, \mathrm{H}_{2} \mathrm{~S}$ and $\mathrm{SO}_{2}$ (Anderson et al., 2007); and as lubricants in different systems (Bermudez et al., 2009).

The use of carbon dioxide $\left(\mathrm{CO}_{2}\right)$ as a green reaction media has gained more and more research interest due to its environmental and nontoxic properties. Carbon dioxide is nonflammable, nontoxic and inexpensive. The most important aspect of $\mathrm{CO}_{2}$ is its tunable properties, which can change significantly with temperature and pressure. $\mathrm{CO}_{2}$ has a relatively low critical temperature $\left(31.1^{\circ} \mathrm{C}\right)$ and moderate critical pressure (73.8 bar) (Jessop and Leitner, 1999). Wu and coworkers (Wu et al., 2005) and Zhou and coworkers (Zhou et al., 2006) investigated the use of compressed and supercritical $\mathrm{CO}_{2}$ as an environmentally benign alternative in ionic liquid synthesis.

The phase behavior of ionic liquids with $\mathrm{CO}_{2}$ is unique. $\mathrm{CO}_{2}$ is very soluble in ionic liquids, but, in contrast, ionic liquids are insoluble in the pure $\mathrm{CO}_{2}$ phase. Therefore, the ionic liquid $+\mathrm{CO}_{2}$ mixture does not become miscible (critical) even at elevated pressures, which makes them advantageous as biphasic reaction media. Moreover, compressed $\mathrm{CO}_{2}$ can increase the solubility of reactive gases $\left(\mathrm{H}_{2}\right.$ and $\left.\mathrm{O}_{2}\right)$ in ionic liquids (Solinas et al., 2004; Hert et al., 2005), and dramatically decreases the melting point of many ionic solids, even inducing melting over $100{ }^{\circ} \mathrm{C}$ below the normal melting points of some ionic solids (Scurto and Leitner, 2006; Scurto et al., 2008).

Phase equilibria in systems composed of ionic liquids $+\mathrm{CO}_{2}$ were studied by several authors (Blanchard et al., 2001; Ren et al., 2010; Nwosu et al., 2009; Carvalho et al., 2009a, 2009b; Kroon et al., 2005; Liu et al., 2003; Blanchard et al., 1999), but few of them have assessed the solubility in ionic liquids of other gases. The phase equilibria of different imidazolium ionic liquids with 1,1,1,2tetrafluoroethane (R-134a) were studied by Ren and Scurto (2009a, 2009b); the authors emphasize the importance of understanding these systems for the separation of hydrofluorocarbon refrigerant gases and in other engineering applications.

In this work, isothermal vapor-liquid equilibrium data for 17 binary mixtures composed of ionic liquids and different gases $\left(\mathrm{CO}_{2}, \mathrm{C}_{2} \mathrm{H}_{6}, \mathrm{CHF}_{3}\right.$ and $\mathrm{R}-134 \mathrm{a})$ were analyzed, totalizing 390 experimental data points distributed in 50 isotherms. Pressure and temperature ranges vary between 1-620 bar and 298.15-363.15 K, respectively. The systems were modeled with the Peng-Robinson (Peng and Robinson, 1976) and Soave-Redlich-Kwong (Soave, 1972) equations of state using the van der Waals mixing rule with two adjustable parameters $\left(\mathrm{k}_{\mathrm{ij}}\right.$ and $\left.\mathrm{l}_{\mathrm{ij}}\right)$. These thermodynamic models were implemented in the PE 2000 software (Pfohl et al., 2000).

\section{THERMODYNAMIC MODELING}

The Soave-Redlich-Kwong equation of state is (Soave, 1972):

$\mathrm{P}=\frac{\mathrm{RT}}{\mathrm{V}-\mathrm{b}}-\frac{\alpha(\mathrm{T})}{\mathrm{V}(\mathrm{V}+\mathrm{b})}$

Here, $\mathrm{P}$ is the pressure, $\mathrm{V}$ the molar volume, $\mathrm{T}$ the temperature, $\alpha(\mathrm{T})$ the temperature-dependent attractive parameter, $\mathrm{b}$ the co-volume and $\mathrm{R}$ the ideal gas constant. The co-volume is temperature independent and is calculated using the critical properties as follows:

$\mathrm{b}=0.08664 \frac{\mathrm{RT}_{\mathrm{C}}}{\mathrm{P}_{\mathrm{C}}}$

The attractive parameter, $\alpha(T)$, is calculated by a Soave-type expression:

$\alpha=\mathrm{a}\left(\mathrm{T}_{\mathrm{C}}, \mathrm{P}_{\mathrm{C}}\right) \cdot\left[1+\mathrm{m} \cdot\left(1-\mathrm{T}_{\mathrm{r}}^{0.5}\right)\right]^{2}$

where:

$\mathrm{a}\left(\mathrm{T}_{\mathrm{C}}, \mathrm{P}_{\mathrm{C}}\right)=0.42748 \frac{\left(\mathrm{RT}_{\mathrm{C}}\right)^{2}}{\mathrm{P}_{\mathrm{C}}}$

Here, $T_{r}$ is the reduced temperature. The parameter $\mathrm{m}$ is correlated to the acentric factor $\omega$ for light non-polar compounds, through the following expression:

$\mathrm{m}=0.480+1.574 \omega-0.176 \omega^{2}$

The expression for the Peng-Robinson equation of state is (Peng and Robinson, 1976):

$P=\frac{R T}{V-b}-\frac{\alpha(T)}{V(V+b)+b(V-b)}$

The variables are the same explained above. Again, the co-volume is temperature independent and is calculated using the critical properties, as follows: 
$\mathrm{b}=0.0778 \frac{\mathrm{RT}_{\mathrm{C}}}{\mathrm{P}_{\mathrm{C}}}$

The attractive parameter, $\alpha(\mathrm{T})$, is calculated by:

$\alpha=\mathrm{a}\left(\mathrm{T}_{\mathrm{C}}, \mathrm{P}_{\mathrm{C}}\right) \cdot\left[1+\mathrm{m} \cdot\left(1-\mathrm{T}_{\mathrm{r}}^{0.5}\right)\right]^{2}$

where:

$\mathrm{a}\left(\mathrm{T}_{\mathrm{C}}, \mathrm{P}_{\mathrm{C}}\right)=0.45724 \frac{\left(\mathrm{RT}_{\mathrm{C}}\right)^{2}}{\mathrm{P}_{\mathrm{C}}}$

Here, the parameter $\mathrm{m}$ is also correlated to the acentric factor, $\omega$, for light non-polar compounds through:

$\mathrm{m}=0.37464+1.54226 \omega-0.26992 \omega^{2}$

The Peng-Robinson equation is widely used in modeling the solubility of substances in supercritical fluids. For mixtures, cubic EoS like PR and SRK are widely applied utilizing the van der Waals-2parameter (vdW-2) mixing rules:

$\alpha_{\text {mix }}=\sum_{\mathrm{i}} \sum_{\mathrm{j}} \mathrm{x}_{\mathrm{i}} \mathrm{x}_{\mathrm{j}} \alpha_{\mathrm{ij}} \quad$ and

$\mathrm{b}_{\text {mix }}=\sum_{\mathrm{i}} \sum_{\mathrm{j}} \mathrm{x}_{\mathrm{i}} \mathrm{x}_{\mathrm{j}} \mathrm{b}_{\mathrm{ij}}$

where the cross energy, $\alpha_{i j}$, and cross co-volume $b_{i j}$ are calculated by combining rules:

$\alpha_{\mathrm{ij}}=\left(\alpha_{\mathrm{i}} \alpha_{\mathrm{j}}\right)^{0.5}\left(1-\mathrm{k}_{\mathrm{ij}}\right)$ and

$b_{i j}=\frac{1}{2}\left(b_{i}+b_{j}\right) \cdot\left(1-l_{i j}\right)$

with $\mathrm{k}_{\mathrm{ij}}=\mathrm{k}_{\mathrm{ji}}$ and $\mathrm{l}_{\mathrm{ij}}=\mathrm{l}_{\mathrm{ji}}$

Here, $\mathrm{k}_{\mathrm{ij}}$ and $\mathrm{l}_{\mathrm{ij}}$ are adjustable parameters, determined by fitting binary phase equilibrium data. The combination of van der Waals mixing rules with the PR-EoS and SRK-EoS provides a good compromise between simplicity and accuracy of the modeling algorithm for representing a large variety of systems (Florusse et al., 2008). Modeling high pressure phase equilibria with this combination showed good correspondence with experimental data in previous work (Gamse and Marr, 2000, 2001).

The software Phase Equilibrium 2000 (PE2000), chosen here to calculate the phase equilibria, was developed by Brunner and coworkers (Pfohl et al, 2000). The software was used by several other researchers (Petkov et al., 2000; Schwarz and Nieuwoudt, 2003a, 2003b; Teodorescu et al., 2003) with excellent results to correlate and predict phase equilibria. PE2000 uses the modified Simplex algorithm (Nelder and Mead, 1965) for parameter regression of the binary interaction parameters, $\mathrm{k}_{\mathrm{ij}}$ and $1_{\mathrm{ij}}$, minimizing the objective function of the average absolute relative deviation ( $\%$ AARD) for liquid and vapor phase mole fractions:

$\%$ AARD $=\frac{100}{N P}\left(\begin{array}{l}\sum_{i=1}^{N}\left|\frac{x_{i}^{\text {exp }}-x_{i}^{\text {pred }}}{x_{i}^{\text {exp }}}\right|+ \\ \sum_{i=1}^{N}\left|\frac{y_{i}^{\text {exp }}-y_{i}^{\text {pred }}}{y_{i}^{\text {exp }}}\right|\end{array}\right)$

Here, $x_{i}^{\exp }$ is the experimental liquid mole fraction data; $x_{i}^{\text {pred }}$ is the predicted value; $y_{i}^{\exp }$ is the experimental vapor mole fraction data; $y_{i}^{\text {pred }}$ is the predicted value and NP is the number of experimental data points. This objective function was used in similar works in the literature with good results (Nwosu et al., 2009; Ren and Scurto, 2009; Ren et al., 2010). Several initial guesses were utilized to avoid the local minima in the regression in order to obtain final values for $\mathrm{k}_{\mathrm{ij}}$ and $\mathrm{l}_{\mathrm{ij}}$.

\section{RESULTS AND DISCUSSION}

The critical properties of ionic liquids were taken from Valderrama et al. (2007, 2008a, 2009), Ren et al. (2010) and Nwosu et al. (2009). For $\mathrm{CO}_{2}, \mathrm{C}_{2} \mathrm{H}_{6}$ and $\mathrm{CHF}_{3}$, the properties were taken from the DIPPR data base (DIADEM, 2000). For R-134a, the critical properties are given by Ren and Scurto (2009a). All critical properties used in this work are given in Table 1.

The solubility of $\mathrm{CO}_{2}, \mathrm{CHF}_{3}$ and $\mathrm{R}-134 \mathrm{a}$ in various ionic liquids was modeled with the PR-EoS and SRK-EoS with the vdW-2 mixing rule, at different temperatures for each case. The experimental data were taken from the literature (Blanchard and Brennecke, 2001; Ren et al., 2010; Nwosu et al., 2009; Carvalho et al., 2009a, 2009b; Kroon et al., 2005; Liu et al., 2003; Ren and Scurto, 2009a; Shariati and Peters, 2003; Florusse et al., 2008) and the characteristics of these systems are shown in Table 2. 
Table 1: Critical properties of pure components.

\begin{tabular}{|c|c|c|c|c|c|}
\hline Compound & Formula & \begin{tabular}{|c|} 
MW \\
$(\mathrm{g} / \mathbf{m o l})$
\end{tabular} & $\begin{array}{l}\mathbf{T}_{\mathbf{C}} \\
(\mathbf{K}) \\
\end{array}$ & $\begin{array}{c}\mathbf{P}_{\mathrm{C}} \\
\text { (bar) }\end{array}$ & $\omega$ \\
\hline Carbon dioxide & $\mathrm{CO}_{2}$ & 44.0 & 304.2 & 73.8 & 0.228 \\
\hline Trifluoromethane & $\mathrm{CHF}_{3}$ & 70.0 & 299.3 & 48.2 & 0.264 \\
\hline 1,1,1,2-tetrafluoroethane & R-134a & 102.0 & 374.3 & 40.6 & 0.327 \\
\hline Ethane & $\mathrm{C}_{2} \mathrm{H}_{6}$ & 30.1 & 305.4 & 48.8 & 0.099 \\
\hline 1-ethyl-3-methyl-imidazolium bis(trifluoromethylsulfonyl)amide & {$[\mathrm{emim}]\left[\mathrm{Tf}_{2} \mathrm{~N}\right]$} & 391.3 & 1244.9 & 32.6 & 0.182 \\
\hline 1-n-hexyl-3-methyl-imidazolium bis(trifluoromethylsulfonyl)amide & {$\left[\mathrm{C}_{6} \mathrm{mim}\right]\left[\mathrm{Tf}_{2} \mathrm{~N}\right]$} & 447.4 & 1287.3 & 23.9 & 0.354 \\
\hline 1-n-decyl-3-methyl-imidazolium bis(trifluoromethylsulfonyl)amide & {$[\mathrm{dmim}]\left[\mathrm{Tf}_{2} \mathrm{~N}\right]$} & 504.0 & 1345.1 & 18.7 & 0.574 \\
\hline 1-n-exyl-3-methyl-imidazolium bromide & {$\left[\mathrm{C}_{6} \mathrm{mim}\right][\mathrm{Br}]$} & 247.2 & 841.1 & 26.7 & 0.607 \\
\hline 1-methylimidazole & 1-methylimidazole & 82.1 & 742.4 & 55.6 & 0.279 \\
\hline 1-n-butyl-3-methyl-imidazolium bis(trifluoromethylsulfonyl)imide & {$[\mathrm{bmim}]\left[\mathrm{Tf}_{2} \mathrm{~N}\right]$} & 419.4 & 826.3 & 27.6 & 0.300 \\
\hline 1-n-pentyl-3-methyl-imidazolium bis(trifluoromethylsulfonyl)imide & {$[\mathrm{pmim}]\left[\mathrm{Tf}_{2} \mathrm{~N}\right]$} & 433.0 & 1249.43 & 26.3 & 0.412 \\
\hline 1-n-octyl-3-methylimidazolium tetrafluoroborate & {$[\mathrm{omin}]\left[\mathrm{BF}_{4}\right]$} & 282.1 & 737.0 & 16.0 & 1.029 \\
\hline 1-n-butyl-3-methylimidazolium tetrafluoroborate & {$[\mathrm{bmin}]\left[\mathrm{BF}_{4}\right]$} & 226.0 & 643.2 & 20.4 & 0.888 \\
\hline 1-ethyl-3-methylimidazolium hexafluorophosphate & {$[\mathrm{emin}]\left[\mathrm{PF}_{6}\right]$} & 256.2 & 663.5 & 19.5 & 0.671 \\
\hline 1-n-butyl-3-methylimidazolium hexafluorophosphate & {$[\mathrm{bmim}]\left[\mathrm{PF}_{6}\right]$} & 284.2 & 708.9 & 17.3 & 0.755 \\
\hline 1-n-butyl-3-methylimidazolium nitrate & {$[\mathrm{bmim}]\left[\mathrm{NO}_{3}\right]$} & 201.1 & 946.3 & 27.3 & 0.604 \\
\hline 1-n-hexyl-3-methylimidazolium tetrafluoroborate & {$\left[\mathrm{C}_{6} \mathrm{mim}\right]\left[\mathrm{BF}_{4}\right]$} & 254.1 & 679.1 & 17.9 & 0.926 \\
\hline 1-n-hexyl-3-methylimidazolium hexafluorophosphate & {$\left[\mathrm{C}_{6} \mathrm{mim}\right]\left[\mathrm{PF}_{6}\right]$} & 312.2 & 754.3 & 15.5 & 0.835 \\
\hline
\end{tabular}

Table 2: Physical characteristics of the binary systems studied in this work.

\begin{tabular}{|c|c|c|c|c|c|c|c|}
\hline \multirow[t]{2}{*}{ System } & \multirow[t]{2}{*}{ Solvent } & \multirow[t]{2}{*}{ Ionic liquid } & \multirow[t]{2}{*}{$\mathbf{N P}^{1}$} & \multicolumn{3}{|c|}{ Range of data } & \multirow[t]{2}{*}{ References } \\
\hline & & & & $\mathbf{T}(\mathbf{K})$ & $\mathbf{P}($ bar) & $\mathbf{x}_{\mathrm{CO} 2}$ & \\
\hline 1 & $\mathrm{CO}_{2}$ & {$[\mathrm{emim}]\left[\mathrm{Tf}_{2} \mathrm{~N}\right]$} & 14 & $323.15-343.15$ & $20-150$ & $0.25-0.75$ & Ren et al. (2010) \\
\hline 2 & $\mathrm{CO}_{2}$ & {$\left[\mathrm{C}_{6} \mathrm{mim}\right]\left[\mathrm{Tf}_{2} \mathrm{~N}\right]$} & 18 & $323.15-343.15$ & $20-250$ & $0.23-0.78$ & Ren et al. (2010) \\
\hline 3 & $\mathrm{CO}_{2}$ & {$[\mathrm{dmim}]\left[\mathrm{Tf}_{2} \mathrm{~N}\right]$} & 14 & $323.15-343.15$ & $15-150$ & $0.26-0.82$ & Ren et al. (2010) \\
\hline 4 & $\mathrm{CO}_{2}$ & {$\left[\mathrm{C}_{6} \operatorname{mim}\right][\mathrm{Br}]$} & 11 & $313.15-333.15$ & $30-150$ & $0.09-0.49$ & Nwosu et al. (2009) \\
\hline 5 & $\mathrm{CO}_{2}$ & 1-methylimidazole & 16 & $313.15-333.15$ & $12-125$ & $0.07-0.95$ & Nwosu et al. (2009) \\
\hline 6 & $\mathrm{CO}_{2}$ & {$[\mathrm{emim}]\left[\mathrm{Tf}_{2} \mathrm{~N}\right]$} & 64 & 298.15-363.15 & $7-310$ & $0.22-0.70$ & Carvalho et al. (2009b) \\
\hline 7 & $\mathrm{CO}_{2}$ & {$[\mathrm{bmim}]\left[\mathrm{Tf}_{2} \mathrm{~N}\right]$} & 32 & $303.15-363.15$ & $7-460$ & $0.23-0.77$ & Carvalho et al. (2009b) \\
\hline 8 & $\mathrm{CO}_{2}$ & {$[\mathrm{pmim}]\left[\mathrm{Tf}_{2} \mathrm{~N}\right]$} & 63 & 298.15-353.15 & $7-570$ & $0.21-0.80$ & Carvalho et al. (2009a) \\
\hline 9 & $\mathrm{CO}_{2}$ & {$[\mathrm{omim}]\left[\mathrm{BF}_{4}\right]$} & 24 & $313.15-333.15$ & $1-94$ & $0.00-0.71$ & Blanchard and Brennecke (2001) \\
\hline 10 & $\mathrm{CO}_{2}$ & {$[\mathrm{bmim}]\left[\mathrm{BF}_{4}\right]$} & 20 & $313.15-353.15$ & $9-620$ & $0.10-0.60$ & Kroon et al. (2005) \\
\hline 11 & $\mathrm{CHF}_{3}$ & {$[\mathrm{emim}]\left[\mathrm{PF}_{6}\right]$} & 20 & $333.15-352.15$ & $17-470$ & $0.10-0.93$ & Shariati and Peters (2003) \\
\hline 12 & $\mathrm{CO}_{2}$ & {$[\mathrm{bmim}]\left[\mathrm{PF}_{6}\right]$} & 43 & $313.15-333.15$ & $1-30$ & $0.00-0.73$ & $\begin{array}{l}\text { Blanchard and Brennecke (2001), } \\
\text { Liu et al. (2003) }\end{array}$ \\
\hline 13 & $\mathrm{CO}_{2}$ & {$[\mathrm{bmim}]\left[\mathrm{NO}_{3}\right]$} & 8 & 333.15 & $1-93$ & $0.00-0.52$ & Blanchard and Brennecke (2001) \\
\hline 14 & R-134a & {$\left[\mathrm{C}_{6} \mathrm{mim}\right]\left[\mathrm{Tf}_{2} \mathrm{~N}\right]$} & 14 & 323.15 & $1-12$ & $0.07-0.76$ & Ren and Scurto (2009a) \\
\hline 15 & R-134a & {$\left[\mathrm{C}_{6} \mathrm{mim}\right]\left[\mathrm{BF}_{4}\right]$} & 7 & 323.15 & $1-12$ & $0.08-0.71$ & Ren and Scurto (2009a) \\
\hline 16 & R-134a & {$\left[\mathrm{C}_{6} \mathrm{mim}\right]\left[\mathrm{PF}_{6}\right]$} & 10 & 323.15 & $1-13$ & $0.07-0.77$ & Ren and Scurto (2009a) \\
\hline 17 & $\mathrm{C}_{2} \mathrm{H}_{6}$ & {$\left[\mathrm{C}_{6} \mathrm{mim}\right]\left[\mathrm{Tf}_{2} \mathrm{~N}\right]$} & 28 & $313.15-353.15$ & 4-130 & $0.05-0.40$ & Florusse et al. (2008) \\
\hline
\end{tabular}

${ }^{1} \mathrm{NP}$ Number of experimental points utilized in this work.

The adjustable parameters, $\mathrm{k}_{\mathrm{ij}}$ and $\mathrm{l}_{\mathrm{ij}}$, the \%AARD and the range of experimental data utilized (expressed in pressure and liquid phase molar composition) are shown in Table 3 for all 17 binary systems analyzed here.

Figure 1 shows the comparison between calculated and experimental data for the mole fraction of liquid phase for all 17 systems at all temperatures, for both EoS analyzed. Analyzing Figure 1 and Table 3, it can be verified that a good correlation between experimental and calculated data was obtained for most of the systems analyzed, with low computing time for all cases. Larger deviations were observed for the SRK equation, as shown in Table 3.

We can see that the solubility of $\mathrm{CO}_{2}, \mathrm{CHF}_{3}$ and $\mathrm{C}_{2} \mathrm{H}_{6}$ increases when the pressure increases and the solubility decreases with the increase of the temperature of the system. This behavior was observed for the two thermodynamics models studied here and also in the experimental data for all systems studied. This behavior is common in VLE. Another important point is that all systems studied here are at elevated pressures, up to 100 bars. In this condition, we can note the upward curvature in the isotherms, i.e., the elevation of the pressure entails very little increase in the gas solubility. 
Table 3: Binary interaction parameters and deviation at different temperatures.

\begin{tabular}{|c|c|c|c|c|c|c|c|c|}
\hline \multirow{2}{*}{ System } & \multicolumn{4}{|c|}{ PR } & \multicolumn{4}{|c|}{ SRK } \\
\hline & $\mathbf{T}(\mathrm{K})$ & $k_{i j}$ & $\mathbf{l}_{\mathrm{ij}}$ & \%AARD & $\mathbf{T}(\mathbf{K})$ & $\mathbf{k}_{\mathrm{ij}}$ & $I_{i j}$ & \%AARD \\
\hline \multirow{2}{*}{1} & 323.15 & 0.045 & 0.048 & 0.91 & 323.15 & 0.026 & 0.029 & 1.33 \\
\hline & 343.45 & 0.017 & 0.025 & 1.27 & 343.15 & 0.024 & 0.037 & 1.31 \\
\hline \multirow{2}{*}{2} & 323.15 & 0.010 & 0.000 & 0.32 & 323.15 & 0.015 & 0.015 & 1.61 \\
\hline & 343.15 & 0.026 & 0.002 & 2.13 & 343.15 & 0.021 & -0.001 & 2.46 \\
\hline \multirow{2}{*}{3} & 323.15 & 0.007 & 0.016 & 1.21 & 323.15 & 0.001 & 0.017 & 1.50 \\
\hline & 343.15 & -0.008 & 0.025 & 0.47 & 343.15 & -0.007 & 0.026 & 0.51 \\
\hline \multirow{2}{*}{4} & 313.15 & 0.040 & -0.068 & 4.77 & 313.15 & 0.042 & -0.066 & 4.71 \\
\hline & 333.15 & 0.040 & -0.068 & 1.29 & 333.15 & 0.043 & -0.066 & 1.25 \\
\hline \multirow{2}{*}{5} & 313.15 & 0.036 & -0.014 & 1.29 & 313.15 & 0.021 & -0.015 & 2.68 \\
\hline & 333.15 & 0.037 & -0.005 & 2.80 & 333.15 & 0.024 & -0.015 & 3.65 \\
\hline \multirow{8}{*}{6} & 298.15 & 0.051 & 0.049 & 0.68 & 298.15 & 0.047 & 0.047 & 0.68 \\
\hline & 303.15 & 0.053 & 0.048 & 0.82 & 303.15 & 0.050 & 0.048 & 0.84 \\
\hline & 313.15 & 0.059 & 0.049 & 1.10 & 313.15 & 0.057 & 0.048 & 1.22 \\
\hline & 323.15 & 0.061 & 0.048 & 1.27 & 323.15 & 0.059 & 0.048 & 1.30 \\
\hline & 333.15 & 0.063 & 0.047 & 1.35 & 333.15 & 0.062 & 0.047 & 1.38 \\
\hline & 343.15 & 0.063 & 0.047 & 1.40 & 343.15 & 0.063 & 0.047 & 1.44 \\
\hline & 353.15 & 0.065 & 0.046 & 1.50 & 353.15 & 0.064 & 0.047 & 1.50 \\
\hline & 363.15 & 0.066 & 0.047 & 1.52 & 363.15 & 0.066 & 0.047 & 1.50 \\
\hline \multirow{4}{*}{7} & 303.15 & 0.166 & 0.139 & 4.07 & 303.15 & 0.172 & 0.136 & 3.82 \\
\hline & 323.15 & 0.134 & 0.117 & 2.63 & 323.15 & 0.137 & 0.117 & 2.65 \\
\hline & 343.15 & 0.144 & 0.118 & 2.74 & 343.15 & 0.148 & 0.118 & 2.72 \\
\hline & 363.15 & 0.155 & 0.120 & 2.68 & 363.15 & 0.160 & 0.120 & 2.62 \\
\hline \multirow{7}{*}{8} & 298.15 & 0.098 & 0.064 & 4.69 & 298.15 & 0.094 & 0.061 & 4.42 \\
\hline & 303.15 & 0.051 & 0.043 & 2.34 & 303.15 & 0.051 & 0.043 & 2.40 \\
\hline & 313.15 & 0.051 & 0.043 & 2.16 & 313.15 & 0.050 & 0.043 & 2.23 \\
\hline & 323.15 & 0.050 & 0.042 & 2.15 & 323.15 & 0.047 & 0.041 & 2.10 \\
\hline & 333.15 & 0.049 & 0.041 & 2.14 & 333.15 & 0.047 & 0.041 & 2.15 \\
\hline & 343.15 & 0.049 & 0.042 & 2.17 & 343.15 & 0.048 & 0.042 & 2.17 \\
\hline & 353.15 & 0.049 & 0.043 & 2.22 & 353.15 & 0.048 & 0.043 & 2.20 \\
\hline \multirow{3}{*}{9} & 313.15 & 0.087 & 0.002 & 1.35 & 313.15 & 0.091 & 0.002 & 1.35 \\
\hline & 323.15 & 0.092 & 0.021 & 1.78 & 323.15 & 0.094 & 0.013 & 1.12 \\
\hline & 333.15 & 0.086 & 0.014 & 1.47 & 333.15 & 0.085 & 0.013 & 1.57 \\
\hline \multirow{3}{*}{10} & 313.15 & 0.203 & 0.059 & 2.09 & 313.15 & 0.199 & 0.050 & 1.11 \\
\hline & 333.15 & 0.211 & 0.047 & 0.84 & 333.15 & 0.229 & 0.053 & 1.24 \\
\hline & 353.15 & 0.234 & 0.044 & 0.85 & 353.15 & 0.253 & 0.052 & 1.46 \\
\hline \multirow{2}{*}{11} & 333 & 0.079 & -0.016 & 6.58 & 333 & 0.098 & 0.003 & 10.44 \\
\hline & 352 & 0.090 & -0.018 & 6.85 & 352 & 0.090 & -0.002 & 6.01 \\
\hline \multirow{3}{*}{12} & 313.15 & 0.098 & 0.010 & 2.46 & 313.15 & 0.101 & 0.008 & 3.01 \\
\hline & 323.15 & 0.118 & 0.037 & 0.75 & 323.15 & 0.121 & 0.036 & 0.97 \\
\hline & 333.15 & 0.119 & 0.059 & 0.84 & 333.15 & 0.110 & 0.032 & 2.28 \\
\hline \multirow{3}{*}{13} & 313.15 & 0.096 & 0.016 & 2.71 & 313.15 & 0.087 & 0.010 & 3.46 \\
\hline & 323.15 & 0.061 & -0.002 & 3.67 & 323.15 & 0.060 & 0.001 & 3.26 \\
\hline & 333.15 & 0.064 & 0.011 & 1.84 & 333.15 & 0.085 & 0.025 & 1.73 \\
\hline 14 & 323.15 & 0.003 & 0.007 & 1.89 & 323.15 & -0.007 & 0.006 & 1.57 \\
\hline 15 & 323.15 & 0.090 & 0.019 & 2.85 & 323.15 & 0.081 & 0.015 & 2.60 \\
\hline 16 & 323.15 & 0.095 & 0.026 & 5.45 & 323.15 & 0.081 & 0.011 & 2.81 \\
\hline \multirow{4}{*}{17} & 313.15 & 0.083 & -0.002 & 1.22 & 313.15 & 0.077 & 0.001 & 1.42 \\
\hline & 323.15 & 0.082 & -0.001 & 1.52 & 323.15 & 0.079 & -0.001 & 1.27 \\
\hline & 333.15 & 0.082 & -0.001 & 1.26 & 333.15 & 0.077 & 0.001 & 1.64 \\
\hline & 353.15 & 0.101 & 0.007 & 0.45 & 353.15 & 0.079 & -0.001 & 1.97 \\
\hline Mean deviation & - & - & - & 2.10 & - & - & - & 2.25 \\
\hline
\end{tabular}




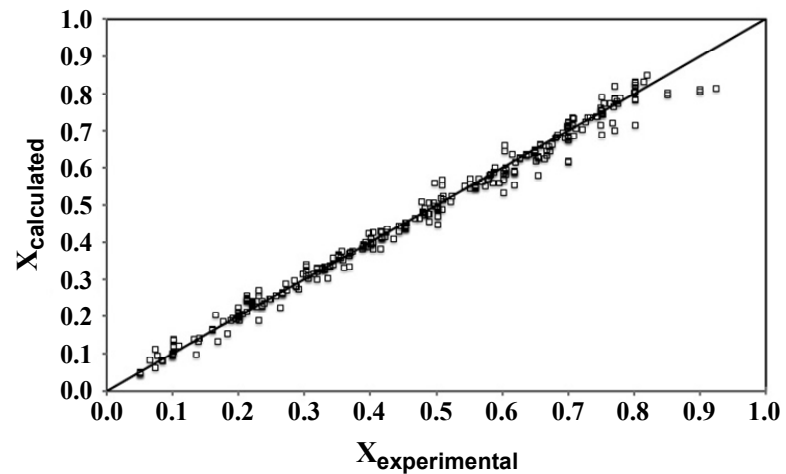

(a)

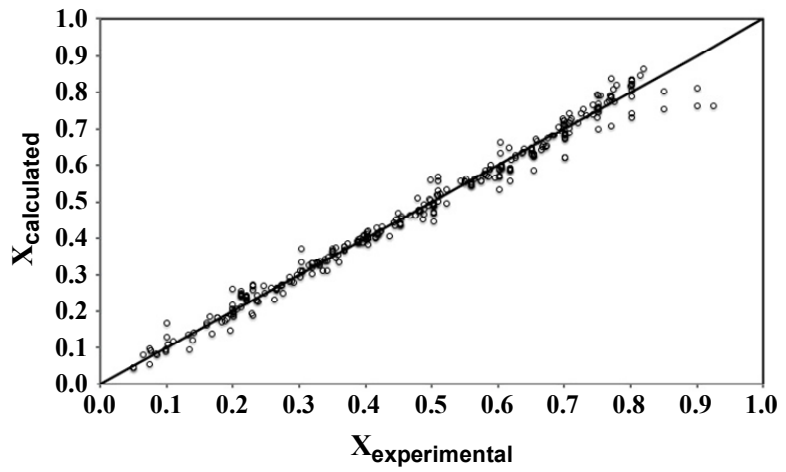

(b)

Figure 1: Comparison of calculated and experimental data for the mole fraction of liquid phase using PR-vdW-2 (a) and SRK-vdW-2 (b).

This behavior was observed in others works in the literature (Shariati and Peters, 2003, 2004; Arce et al., 2010). The solubility of $\mathrm{CO}_{2}$ in ionic liquids follows a linear relationship with the length of alkyl chain. This relationship directly influences the prediction of data across equations of state, since the greater the solubility, the lower the error displayed, as seen for the systems studied (Shariati et al., 2005).

Overall, both EoS tested provided a good correlation for the bubble point data in the pressure range of the experimental data utilized, but the correlation was poor in the high pressure region for most systems. This behavior can be seen in Figure 1 in the high gas concentration ( $\mathrm{x}_{\text {experimental}}$ ) region of the graph. The high concentration of the gas coincides with the high pressure conditions for all systems.

Larger deviations in the regions of high pressure were described in other works in the literature (Carvalho et al., 2009a; Nwosu et al., 2009; Ren et al., 2010) and, because of this behavior, the extrapolation of the model much beyond the data pressure region in which the interaction parameters were fit is not recommended.

For some systems, the combination of the vdW-2 mixing rule with the PR and SRK Eos did not provide a good correlation between experimental and calculated data, mainly to represent the liquid phase. This behavior was expected due to the high complexity of the systems reviewed here. A possible solution to this problem would be to use more elaborate mixing rules, such as the Wong-Sandler (WS) type mixing rules (Wong and Sandler, 1992).

Some papers present the modeling of systems composed of ionic liquid and gas, principally $\mathrm{CO}_{2}$, using the combination of PR and WS mixing rules with good representation of the thermodynamic behavior, such as Alvarez et al. (2008) (PR+WS combined with NRTL model); Valderrama et al. (2008b) (PR+WS combined with the Van Laar model); Arce et al. (2010) (PRSV-Peng Robinson+ Stryjek-Vera EoS combined with the WS mixing rule and the Van Laar model) and Chilla et al. (2011) $(\mathrm{PR}+\mathrm{WS}$ combined with the Van Laar model).

In Table 4, the deviations presented in different papers and the deviations observed in this paper for the liquid phase (\%AARDL, given by Equation (14)) are compared. The deviations were presented only for the liquid phase because in these papers the calculations were performed only for the mole fraction of the liquid phase.

Table 4: Average absolute deviation in the liquid molar fraction and for the pressure in the present work and in some works in the literature.

\begin{tabular}{|c|c|c|c|c|}
\hline Reference & Thermodynamic model & Parameters & Observed deviation (\%) & Mixtures studied \\
\hline Alvarez et al. (2008) & PR/WS/NRTL & 3 & $3.3^{1}$ & 1 \\
\hline Valderrama et al. (2008) & $\mathrm{PR} / \mathrm{WS} / \mathrm{VL}$ & 3 & $3.0^{1}$ & 8 \\
\hline \multirow{2}{*}{ Valderrama et al. (2012) } & $\mathrm{PR} / \mathrm{WS} / \mathrm{VL}$ & 3 & $5.3^{1}$ & 6 \\
\hline & $\mathrm{PR} / \mathrm{WS} / \mathrm{NRTL}$ & 3 & $7.3^{1}$ & 6 \\
\hline \multirow{2}{*}{ Arce et al. (2010) } & $\mathrm{PRSV} / \mathrm{WS} / \mathrm{VL}$ & 6 & $3.6^{1}$ & 17 \\
\hline & PRSV-vdW1 & 2 & $2.6^{1}$ & 17 \\
\hline Chilla et al. (2011) & $\mathrm{PR} / \mathrm{WS} / \mathrm{VL}$ & 3 & $1.5^{2}$ & 5 \\
\hline Ren and Scurto (2009) & PR-vdW-2 & 2 & $4.0^{2}$ & 4 \\
\hline Ren et al. (2010) & PR-vdW-2 & 2 & $2.9^{2}$ & 3 \\
\hline Jang et al. (2010) & PR-vdW-2 & 2 & $6.4^{2}$ & 1 \\
\hline \multirow{2}{*}{ This work } & PR-vdW-2 & 2 & $4.0^{2}$ & 17 \\
\hline & SRK-vdW-2 & 2 & $4.4^{2}$ & 17 \\
\hline
\end{tabular}

${ }^{1}$ pressure deviations $(\Delta \mathrm{P} \%) ;{ }^{2}$ liquid mole fraction deviations $(\Delta \mathrm{x} \%)$. 
$\% A A R D L=\frac{100}{N P}\left(\sum_{i=1}^{N}\left|\frac{x_{i}^{\text {exp }}-x_{i}^{\text {pred }}}{x_{i}^{\exp }}\right|\right)$

Most of the papers that used the combination of PR EoS combined with the WS mixing rule showed minor deviations when compared with those that used the PR EoS combined with the vdW-2 mixing rule (see Table 4). In papers that used the same combination used in this paper (PR-vdW2), similar deviations were observed. Works that used the SRK Eos for this type of system were not found in the literature and the comparison was not possible.

\section{Effect of Gas on $\left[\mathrm{C}_{6} \mathrm{mim}\right]\left[\mathrm{Tf}_{2} \mathrm{~N}\right]$ Phase Behavior at $323.15 \mathrm{~K}$}

The solubility of three different gases ( $\mathrm{R}-134 \mathrm{a}$, $\mathrm{CO}_{2}$ and $\mathrm{C}_{2} \mathrm{H}_{6}$ ) was analyzed in $\left[\mathrm{C}_{6} \mathrm{mim}\right]\left[\mathrm{Tf}_{2} \mathrm{~N}\right]$ ionic liquid. The solubility of R-134a is greater than that of the other gases at $323.15 \mathrm{~K}$ (lower pressure results in higher solubility when compared with the other gases). The results can be seen in Figure 2. This behavior can be explained by the similarity between the molecules of $\left[\mathrm{C}_{6} \mathrm{mim}\right]\left[\mathrm{Tf}_{2} \mathrm{~N}\right]$ and $\mathrm{R}-134 \mathrm{a}$ in terms of polarity.

\section{Effect of Anion Modification on $\mathrm{CO}_{2}$ and R-134a Solubility}

The anion effect on $\mathrm{CO}_{2}$ and $\mathrm{R}-134 \mathrm{a}$ solubility can be seen in Figures 3 (a) and (b), respectively. For $\mathrm{CO}_{2}$ solubility, the anion effect is analyzed at $333.15 \mathrm{~K}$ for the cation 1-butyl-3-methylimidazolium ([bmim]) with the following anions: hexafluorophosphate $\left(\left[\mathrm{PF}_{6}\right]\right)$, tetrafluoroborate $\left(\left[\mathrm{BF}_{4}\right]\right)$ and nitrate $\left(\left[\mathrm{NO}_{3}\right]\right)$.

As can be seen in Figure 3 (a), $\mathrm{CO}_{2}$ is more soluble in $\left[\mathrm{PF}_{6}\right]$ than in $\left[\mathrm{BF}_{4}\right]$ and $\left[\mathrm{NO}_{3}\right]$, but the solubility in $\left[\mathrm{NO}_{3}\right]$ is approximately equal to the solubility in $\left[\mathrm{BF}_{4}\right]$ at pressures up to 80 bar.
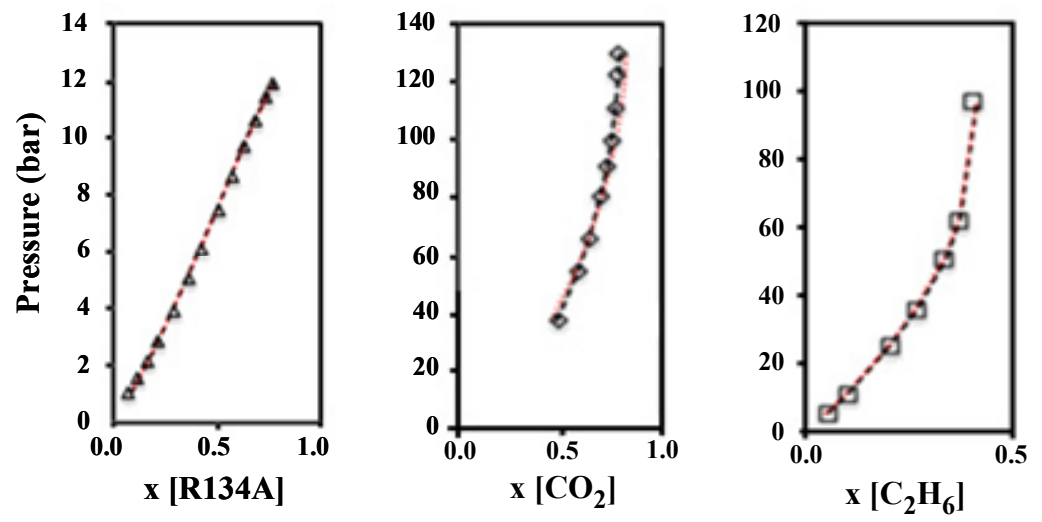

Figure 2: VLE correlation results for systems $\left[\mathrm{C}_{6} \operatorname{mim}\right]\left[\mathrm{Tf}_{2} \mathrm{~N}\right]+\mathrm{R}-134 \mathrm{a}, \mathrm{CO}_{2}$ and $\mathrm{C}_{2} \mathrm{H}_{6}$ at $323.15 \mathrm{~K}$. Symbols: $(\Delta) \mathrm{R}-134 \mathrm{a},(\diamond) \mathrm{CO}_{2},(\square) \mathrm{C}_{2} \mathrm{H}_{6}$. Experimental data were taken from Ren et al. (2010); Ren and Scurto (2009a); and Florusse et al. (2008),(---) PR-EoS + vdW2, (․) SRK-EoS + vdW-2.

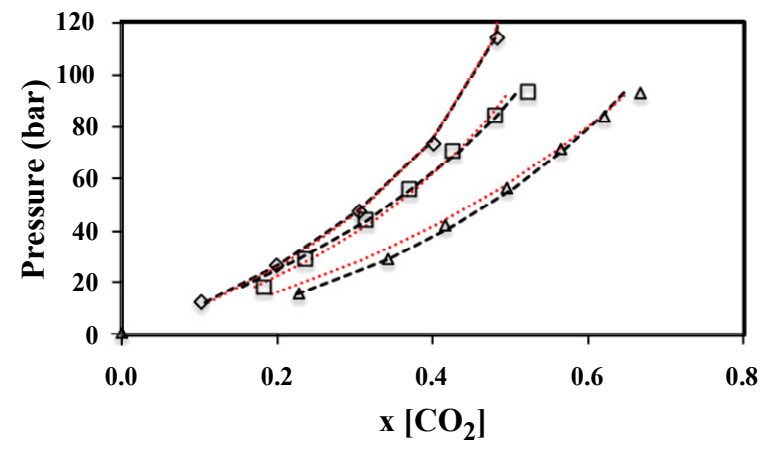

(a)

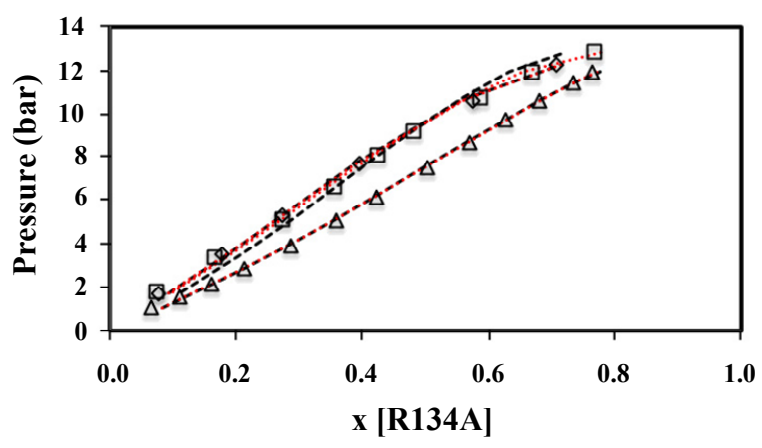

(b)

Figure 3: (a) VLE correlation results for the systems $\mathrm{CO}_{2}+[\mathrm{bmim}]\left[\mathrm{PF}_{6}\right]$, $[\mathrm{bmim}]\left[\mathrm{BF}_{4}\right]$ and $[\mathrm{bmim}]\left[\mathrm{NO}_{3}\right]$. Symbols: $(\Delta)[\mathrm{bmim}]\left[\mathrm{PF}_{6}\right],(\diamond)[\mathrm{bmim}]\left[\mathrm{BF}_{4}\right],(\square)[\mathrm{bmim}]\left[\mathrm{NO}_{3}\right]$ at $333.15 \mathrm{~K},(--)$ PR-EoS $+\mathrm{vdW} 2,(\cdots)$ SRK-EoS + vdW-2.(b)VLE correlation results for the systems R-134a $+\left[\mathrm{C}_{6} \mathrm{mim}\right]\left[\mathrm{Tf}_{2} \mathrm{~N}\right],\left[\mathrm{C}_{6} \mathrm{mim}^{\mathrm{mim}}\right]\left[\mathrm{BF}_{4}\right]$, and $\left[\mathrm{C}_{6} \mathrm{mim}\right]\left[\mathrm{PF}_{6}\right]$. Symbols: $(\Delta)\left[\mathrm{C}_{6} \mathrm{mim}\right]\left[\mathrm{Tf}_{2} \mathrm{~N}\right],(\diamond)\left[\mathrm{C}_{6} \mathrm{mim}\right]\left[\mathrm{BF}_{4}\right],(\square)\left[\mathrm{C}_{6} \mathrm{mim}\right]\left[\mathrm{PF}_{6}\right]$ at $323.15 \mathrm{~K}$. (---) PR-EoS + vdW2,(․) SRK-EoS + vdW-2. 
For R-134a solubility, the anion effect is analyzed at $323.15 \mathrm{~K}$ for the cation 1-hexyl-3-methylimidazolium with the following anions: bis(trifluoromethylsulfonyl) imide $\left(\left[\mathrm{Tf}_{2} \mathrm{~N}\right]\right),\left[\mathrm{BF}_{4}\right]$ and $\left[\mathrm{PF}_{6}\right]$.

As can be seen in Figure 3 (b), R-134a is more soluble in $\left[\mathrm{Tf}_{2} \mathrm{~N}\right]$ than in $\left[\mathrm{BF}_{4}\right]$ and $\left[\mathrm{PF}_{6}\right]$. The anions $\left[\mathrm{BF}_{4}\right]$ and $\left[\mathrm{PF}_{6}\right]$ have a very similar solubility for this gas for the whole range of pressure studied here.

The solubility parameter depends on the energy of vaporization and molar volume. Generally, the energy of vaporization is high for all IL, so because the $\left[\mathrm{Tf}_{2} \mathrm{~N}\right]$ anion is larger than other anions, such as $\left(\left[\mathrm{PF}_{6}\right]\right.$ or $\left.\left[\mathrm{BF}_{4}\right]\right)$ its molar volume is significantly larger and therefore $\left[\mathrm{Tf}_{2} \mathrm{~N}\right]$ dissolves $\mathrm{CO}_{2}$ to a greater degree.

\section{Effect of Cation Modification on $\mathrm{CO}_{2}$ Solubility}

Figure 4 shows the effect of the cation modification on the $\mathrm{CO}_{2}$ solubility for the following1-alkyl-3methylimidazolium bis(trifluoromethylsulfonyl)imide ionic liquids: [dmim] $\left[\mathrm{Tf}_{2} \mathrm{~N}\right],\left[\mathrm{C}_{6} \mathrm{mim}\right]\left[\mathrm{Tf}_{2} \mathrm{~N}\right],\left[\mathrm{C}_{2} \mathrm{mim}\right]$ $\left[\mathrm{Tf}_{2} \mathrm{~N}\right],[\mathrm{pmim}]\left[\mathrm{Tf}_{2} \mathrm{~N}\right]$ and $[\mathrm{bmim}]\left[\mathrm{Tf}_{2} \mathrm{~N}\right]$.

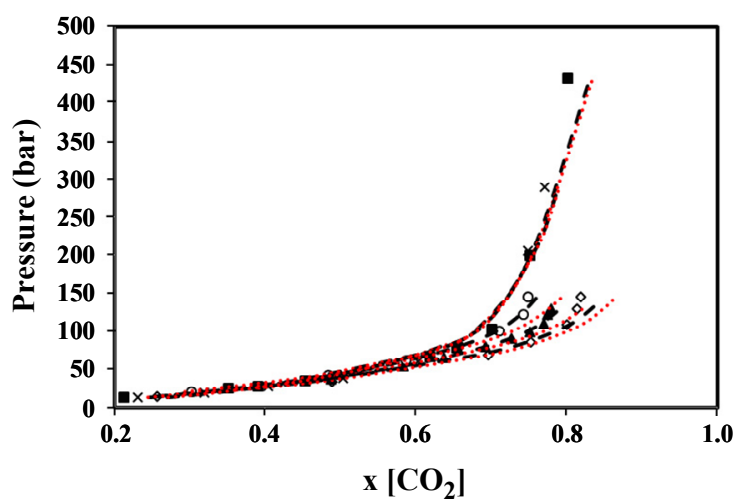

Figure 4: VLE correlation results for the systems $\mathrm{CO}_{2}+[\mathrm{dmim}]\left[\mathrm{Tf}_{2} \mathrm{~N}\right], \mathrm{CO}_{2}+\left[\mathrm{C}_{6} \operatorname{mim}\right]\left[\mathrm{Tf}_{2} \mathrm{~N}\right], \mathrm{CO}_{2}$ $+\left[\mathrm{C}_{2} \operatorname{mim}\right]\left[\mathrm{Tf}_{2} \mathrm{~N}\right], \mathrm{CO}_{2}+[\mathrm{pmim}]\left[\mathrm{Tf}_{2} \mathrm{~N}\right]$ and $\mathrm{CO}_{2}+$ [bmim $]\left[\mathrm{Tf}_{2} \mathrm{~N}\right]$. Symbols: $(\diamond)[\mathrm{dmim}]\left[\mathrm{Tf}_{2} \mathrm{~N}\right], \quad(\boldsymbol{\Delta})$ $\left[\mathrm{C}_{6} \operatorname{mim}\right]\left[\mathrm{Tf}_{2} \mathrm{~N}\right],(\mathrm{O})\left[\mathrm{C}_{2} \mathrm{mim}\right]\left[\mathrm{Tf}_{2} \mathrm{~N}\right],(\mathbf{\bullet})[\mathrm{pmim}]\left[\mathrm{Tf}_{2} \mathrm{~N}\right]$ and (x) $[\mathrm{bmim}]\left[\mathrm{Tf}_{2} \mathrm{~N}\right]$ at $323.15 \mathrm{~K}$. (--) PR-EoS + vdW2, ()SRK-EoS + vdW-2.

Furthermore, the solubility of $\mathrm{CO}_{2}$ is also strongly dependent on the alkyl chain length of the ionic liquid; similar results were observed in the works of Shariati and Peters (2005) and Shin et al. (2008). In general, the solubility in IL increases with the increase of the length of the alkyl chain of the IL.

Additionally, the dramatic difference in size between $\mathrm{CO}_{2}$ and an IL emphasizes the influence of the entropic effect on the solubility. The large entropic effect led to a negative deviation from the ideal solubility that might explain why $\mathrm{CO}_{2}$ is more soluble in the larger 1-decyl- than in the smaller 1-ethyl-3-methylimidazolium IL`s (Cadena et al., 2004; Anthony et al., 2005).

\section{CONCLUSION}

Pressure-composition diagrams for 17 different binary systems of ionic liquids $+\mathrm{CHF}_{3}, \mathrm{C}_{2} \mathrm{H}_{6}, \mathrm{CO}_{2}$ and $\mathrm{R}-134 \mathrm{a}$ at high pressure were modeled at different temperatures with the PR and SRK equations of state and the vdW-2 mixing rule. Solubilities of all gases studied in this work decrease with an increase in the temperature of the system, and increase with increasing pressure. Predicted results were highly satisfactory for both EoS analyzed, with AARD\% between experimental and calculated data of $2.10 \%$ and $2.25 \%$ for PR-vdW-2 and SRK-vdW-2, respectively.

\section{NOMENCLATURE}

\section{List of Symbols}

\begin{tabular}{|c|c|}
\hline $\begin{array}{l}\text { a } \\
\% \text { AARD }\end{array}$ & $\begin{array}{l}\text { EoS attractive parameter } \\
\text { average absolute relative } \\
\text { deviation }\end{array}$ \\
\hline$\%$ AARDL & $\begin{array}{l}\text { average absolute relative } \\
\text { deviation for the liquid phase }\end{array}$ \\
\hline$b$ & EoS co-volume parameter \\
\hline EoS & equation of state \\
\hline IL & ionic liquid \\
\hline $\mathrm{k}_{\mathrm{ij}}$ & $\begin{array}{l}\text { binary interaction parameter } \\
\text { for the attractive parameter }\end{array}$ \\
\hline $1_{\mathrm{ij}}$ & $\begin{array}{l}\text { binary interaction parameter } \\
\text { for the co-volume parameter }\end{array}$ \\
\hline $\mathrm{m}$ & $\begin{array}{l}\text { parameter defined in the } \\
\text { function } \alpha\end{array}$ \\
\hline MW & molecular weight \\
\hline NP & $\begin{array}{l}\text { number of experimental data } \\
\text { points }\end{array}$ \\
\hline NRTL & $\begin{array}{l}\text { Non Random Two Liquid } \\
\text { model }\end{array}$ \\
\hline $\mathrm{P}_{\mathrm{C}}$ & critical pressure \\
\hline PR & Peng-Robinson EoS \\
\hline PRSV & $\begin{array}{l}\text { Peng-Robinson Stryjek-Vera } \\
\text { EoS }\end{array}$ \\
\hline $\mathrm{R}$ & universal gas constant \\
\hline SRK & Soave-Redlich-Kwong EoS \\
\hline $\mathrm{T}_{\mathrm{C}}$ & critical temperature \\
\hline
\end{tabular}




$\begin{array}{ll}\mathrm{T}_{\mathrm{R}} & \begin{array}{l}\text { reduced temperature } \\ \text { vdW - } 1\end{array} \\ & \begin{array}{l}\text { classic van der Waals mixing } \\ \text { rule with 1 adjustable } \\ \text { parameter }\end{array} \\ \text { vdW - 2 } & \begin{array}{l}\text { classic van der Waals mixing } \\ \text { rule with } 2 \text { adjustable } \\ \text { parameters }\end{array} \\ & \text { Van Laar model } \\ \mathrm{VL} & \text { vapor liquid equilibria } \\ \mathrm{VLE} & \text { Wong Sandler } \\ \mathrm{WS} & \text { mole fraction in liquid phase } \\ \mathrm{x} & \text { mole fraction in vapor phase }\end{array}$

\section{Superscripts}

$\begin{array}{ll}\text { exp } & \text { experimental } \\ \text { pred } & \text { predicted }\end{array}$

\section{Subscripts}

$$
\begin{array}{ll}
\mathrm{i}, \mathrm{j} & \text { component } \\
\text { mix } & \text { mixture } \\
\mathrm{C} & \text { critical }
\end{array}
$$

\section{Greek Letters}

$\begin{array}{ll}\alpha & \text { auxiliary parameter } \\ \omega & \text { acentric factor }\end{array}$

\section{ACKNOWLEDGEMENTS}

The authors gratefully acknowledge the financial support from CAPES. M. Aznar and R. Guirardello are recipients of fellowships from $\mathrm{CNPq}$.

\section{REFERENCES}

Alvarez, V. H., Larico, R., Ianos, Y., Aznar, M., Parameter estimation for VLE calculation by global minimization: the genetic algorithm. Braz. J. Chem. Eng., 25, 409 (2008).

Anderson, J. L., Dixon, J. K., Brennecke, J. F., Solubility of $\mathrm{CO}_{2}, \mathrm{CH}_{4}, \mathrm{C}_{2} \mathrm{H}_{6}, \mathrm{C}_{2} \mathrm{H}_{4}, \mathrm{O}_{2}$ and $\mathrm{N}_{2}$ in 1hexyl-3-methylpyridinium bis (trifluoromethylsulfonyl) imide: comparison to other ionic liquids. Acc. Chem. Res., 40, 1208 (2007).

Anthony, J. L., Anderson, J. L., Maginn, E. J., Brennecke, J. F., Anion effects on gas solubility in ionic liquids. J. Phys. Chem., B, 109, 6366 (2005).

Anthony, J. L., Maginn, E. J., Brennecke, J. F., Solubilities and thermodynamics properties of gases in the ionic liquid 1-n-butyl-3methylimidazolium hexafluorophosphate. J. Phys. Chem., B, 106, 7315 (2002).

Anthony, J. L., Maginn, E. J., Brennecke, J. F., Solution thermodynamics of imidazolium based ionic liquids and water. J. Phys. Chem., B, 105, 10942 (2001).

Arce, P. F., Robles, P. A., Graber, T. A., Aznar, M., Modeling of high-pressure vapor-liquid equilibrium in ionic liquids + gas systems using the PRSV equation of state. Fluid Phase Equilib., 295, 9 (2010).

Bermudez, M. D., Jiménez, A. E., Sanes, J., Carrion. J. F., Ionic liquid as advanced lubricant fluids. Molecules, 14, 2888 (2009).

Blanchard, L. A., Brennecke, J. F., Recovery of organic products from ionic liquids using supercritical carbon dioxide. Ind. Eng. Chem. Res., 40, 287 (2001).

Blanchard, L. A., Gu, Z., Brennecke, J. F., High pressure phase behavior of ionic liquids $/ \mathrm{CO}_{2}$ systems. J. Phys. Chem., B, 105, 2437 (2001).

Blanchard, L. A., Hancu, D., Beckman, E. J., Brennecke, J. F., Green processing using ionic liquids and $\mathrm{CO}_{2}$. Nature, 399, 28 (1999).

Cadena, C., Anthony, J. L., Shah, J. K., Morrow, T. I., Brennecke, J. F., Maginn, E. J., Why is $\mathrm{CO}_{2}$ so soluble in imidazolium based ionic liquids? J. Am. Chem. Soc., 126, 5300 (2004).

Carvalho, P. J., Álvarez, V. H., Machado, J. J. B., Pauly, J., Daridon, J. L., Marrucho, I. M., Aznar, M., Coutinho, J. A. P. High pressure phase behavior of carbon dioxide in 1-alkyl-3methylimidazolium bis (trifluoromethylsulfonyl) imide ionic liquids. J. Supercrit. Fluids, 48, 99 (2009b).

Carvalho, P. J., Álvarez, V. H., Marrucho, I. M., Aznar, M., Coutinho, J. A. P., High pressure phase behavior of carbon dioxide in 1-butyl-3methylimidazolium bis (trifluormethylsulfonyl) imide and 1-butyl-3methylimidazolium dicyanamide ionic liquids. J. Supercrit. Fluids, 50, 105 (2009a).

Chilla, L. O. P., Lazzús, J. A., Pérez-Ponce, A. A., Particle swarm modeling of vapor liquid equilibrium data of binary system containing $\mathrm{CO}_{2}$ + imidazolium ionic liquids based on bis [(trifluoromethyl)sulfonyl] imide anion. J. Eng. Thermophys., 20, 487 (2011).

DIADEM Public v. 1.2 - DIPPR $®$ - Design Institute for Physical Property Data. Information and Data Evaluation Manager (2000).

Fadeev, A. G., Meagher, M. M. Opportunities for ionic liquids in recovery of biofuels. Chem. Commun., 295, 295 (2001). 
Florusse, L. J., Raeissi, S., Peters, C. J., High-pressure phase behavior of ethane with 1-hexyl-3methylimidazolium bis(trifluoromethylsulfonyl)imide. J. Chem. Eng. Data, 53, 1283 (2008).

Gamse, T., Marr, R., High-pressure phase equilibria of the binary systems carvone-carbon dioxide and limonene-carbon dioxide at 30,40 and $50^{\circ} \mathrm{C}$. Fluid Phase Equilib., 171, 165 (2000).

Gamse, T., Marr, R., Phase equilibrium properties of the 1-phenylethanol-carbon dioxide and 2octanol-carbon dioxide binary system at 303.15 , 313.15 and 323.15 K. J. Chem. Eng. Data, 46, 117 (2001).

Hermann, W. A., Bohn, V. P. W., Heck reaction catalized by phospha-palladacycles in nonaqueous ionic liquids. J. Organomet. Chem., 572, 141 (1999).

Hert, D. G., Anderson, J. L., Aki, S. N. V. K., Brennecke, J. F., Enhancement of oxygen and methane solubility in 1-hexyl-3-methylimidaxolium bis(trifluoromethylsulfonyl)imide using carbon dioxide. Chem. Comm., 20, 2603 (2005).

Jang, S., Cho, D. W., Im, T., Kim, H., High pressure phase behavior of $\mathrm{CO}_{2}+1$-butyl-3-methylimidazolium chloride system. Fluid Phase Equilib., 299, 216 (2010).

Jessop, P. G., Leitner, W., Chemical Synthesis Using Supercritical Fluids. Wiley-VCH: Weinheim (1999).

Kroon, M. C., Shariati, A., Costantini, M., van Spronsen, J., Witkamp, G. J., Sheldon, R. A., Peters, C. J., High-pressure phase behavior of systems with ionic liquids: Part V. The binary system carbon dioxide + 1-butyl-3-methylimidazolium tetrafluoroborate. J. Chem. Eng. Data, 50, 173 (2005).

Liu, Z., Wu, W., Han, B., Dong, Z., Zhao, G., Wang, J., Jiang, T., Yang, G., Study on the phase behaviors, viscosities, and thermodynamic properties of $\mathrm{CO}_{2} /\left[\mathrm{C}_{4} \mathrm{mim}\right]\left[\mathrm{PF}_{6}\right] /$ methanol system at elevated pressure. Chem. Eur. J., 9, 3897 (2003).

Nelder, J. A., Mead, R., A Simplex method for function minimization. Comput. J., 7, 308 (1965).

Nwosu, S. O., Schleicher, J. C., Scurto, A. M., Highpressure phase equilibria for the synthesis of ionic liquids in compressed $\mathrm{CO}_{2}$ for 1-hexyl3methylimidazolium bromide with 1-bromohexane and 1 methylimidazolium. J. Supercrit. Fluids, 51, 1 (2009).

Peng, D. Y., Robinson, D. B., A new two-constant equation of state. Ind. Eng. Chem. Res., 15, 59 (1976).

Petkov, S., Pfohl, O., Brunner, G., PE 2000 allows for implementation of EOS by users. 18th European Seminar on Applied Thermodynamics;
KutnáHora, Czech Republic, June 8-11, 2000. Abstract 2 (2000).

PFohl, O., Petkov, S., Brunner, G., PE2000: A Powerful Tool to Correlate Phase Equilibrium. Herbert UtzVerlag, München (2000).

Ren, W., Scurto, A. M., Global phase behavior of imidazolium ionic liquids in compressed 1,1,1,2tetrafluoroethane (R-134a). AIChE J., 55, 486 (2009b).

Ren, W., Scurto, A. M., Phase equilibria of imidazolium ionic liquids and the refrigerant gas 1,1,1,2 - tetrafluoroethane (R-134a). Fluid Phase Equilib., 286, 1 (2009a).

Ren, W., Sensenich, B., Scurto, A. M., High-pressure phase equilibria of \{carbon dioxide $\left(\mathrm{CO}_{2}\right)+n$-alkylimidazolium bis(trifluoromethylsulfonyl) amide ionic liquids. J. Chem. Thermodyn., 42, 305 (2010).

Schwarz, C. E., Nieuwoudt, L., Phase equilibrium of propane and alkanes. Part II: Hexatriacontane through hexacontane. J. Supercrit. Fluid, 27, 145 (2003a).

Schwarz, C. E., Nieuwoudt, L., Phase equilibrium of propane and alkanes. Part I. Experimental procedures, dotriacontane equilibrium and EOS modeling. J. Supercrit. Fluid, 27, 133 (2003b).

Scurto, A. M., Leitner, W., Expanding the useful range of ionic liquids: melting point depression of organic salts with carbon dioxide for biphasic catalytic reactions. Chem. Comm., 35, 3681 (2006).

Scurto, A. M., Newton, E., Weikel, R. R., Draucker, L., Hallett, J., Liotta, C. L., Leitner, W., Eckert, C. A., Melting point depression of ionic liquids with $\mathrm{CO}_{2}$ : Phase equilibria. Ind. Eng. Chem. Res., 47, 493 (2008).

Seddon, K. R., Room temperature ionic liquids: Neoteric solvents for clean catalysis. Kinet. Catal., 37, 693 (1995).

Shariati, A., Peters, C. J., High pressure phase behavior of systems with ionic liquids: Measurements and modeling of the binary systems fluoroform + 1-ethyl-3-methylimidazolium hexafluorophosphate. J. Supercrit. Fluids, 25, 109 (2003).

Shariati, A., Gutkowski, K., Peters, C. J., Comparison of the phase behavior of some selected binary systems with ionic liquids. Phys. Chem. Mol. Thermodyn., 51, 1532 (2005).

Shariati, A., Peters, C. J., High pressure phase equilibria of systems with ionic liquids. J. Supercrit. Fluids, 34, 171 (2005).

Shariati, A., Peters, C. J., High-pressure phase behavior of systems with ionic liquids: Part III. The binary system carbon dioxide +1 -hexyl-3methylimidazolium hexafluorophosphate. J. 
Supercrit. Fluids, 30, 139 (2004).

Shin, E. K., Lee, B. C., Lim, J. S., High pressure solubilities of carbon dioxide in ionic liquids: 1-alkil3-methylimidazolium bis(trifluoromethylsulfonyl) imide. J. Supercrit. Fluids, 45, 282 (2008).

Soave, G., Equilibrium constants from a modified Redlich-Kwong equation of state. Chem. Eng. Sci., 27, 1197 (1972).

Solinas, M., Pfaltz, A., Cozzi, P. G., Leitner, W., Enantio-selective hydrogenation of imines in ionic liquid / carbon dioxide media. J. Am. Chem. Soc., 126, 16142 (2004).

Souza, R. F., Padilha, J. C., Gonçalves, R. S., Dupont, J., Room temperature dialkylimidazolium ionic liquids-based fuel cells. Electrochem. Comm., 5, 728 (2003).

Teodorescu, M., Lugo, L., Fernandez, J., Modeling of gas solubility data for HFCs-lubricant oil binary systems by means of the SRK equation of state. Int. J. Thermophys., 24, 1043 (2003).

Valderrama, J. O., Urbina, F., Faúndez, C. A., Gas Liquid equilibrium modeling of mixtures containing supercritical carbon dioxide and an ionic liquid. J. Supercrit. Fluids, 64, 32 (2012).

Valderrama, J. O., Reategui, A., Sanga, W. W., Thermodynamic consistency test of vapor-liquid equilibrium data for mixtures containing ionic liquids. Ind. Eng. Chem. Res., 47, 1318 (2008b).

Valderrama, J. O., Robles, P. A., Critical properties, normal boiling temperatures, and acentric factors of fifty ionic liquids. Ind. Eng. Chem. Res., 46, 1338 (2007).

Valderrama, J. O., Rojas, R. E., Critical properties of ionic liquids revisited. Ind. Eng. Chem. Res., 48, 6890 (2009).

Valderrama, J. O., Sanga, W. W., Lazzús, J. A., Critical properties, normal boiling temperature, and acentric factor of another 200 ionic liquids. Ind. Eng. Chem. Res., 47, 1318 (2008a).

Visser, A. E., Swatloskim, W. M., Reichert, W. M., Griffin, S. T., Rogers, R. D., Traditional extractants in nontraditional solvents: groups 1 and 2 extraction by crown ethers in room temperature ionic liquids. Ind. Eng. Chem. Res., 39, 3596 (2000).

Welton, T., Room temperature ionic liquids. Solvents for synthesis and catalysis. Chem. Rev., 99, 2071 (1999).

Wong, D. S. H., Sandler, S. I., A theoretically correct mixing rule for cubic equations of state. AIChE J., 38, 671 (1992).

Wu, W., Li, W., Han, B., Zhang, Z., Jiang, T., Liu. Z., A green and effective method to synthesize ionic liquids: Supercritical $\mathrm{CO}_{2}$ Route. Green Chem., 7, 701 (2005).

Zhang, S., Chen, Y., Li, F., Lu, X., Dai, W., Mori, R., Fixation and conversion of $\mathrm{CO}_{2}$ using ionic liquids. Catal. Today, 115, 61 (2006).

Zhou, Z., Wang, T., Xing, H., Butyl-3-methylimidazolium chloride preparation in supercritical carbon dioxide. Ind. Eng. Chem. Res., 45, 525 (2006). 